\title{
Assessing the Implementation of the Deregulation Policy of the Nigerian National Petroleum Corporation (NNPC) (2003 - 2012)
}

OKARAH, Anthony Chidiebere | NDAGUBA, Emeka Austin

\section{Abstract}

$\mathrm{T}$

he Nigerian oil and gas sector plays a very dominant role in the nation's economy with over 90\% in 2011 and 98\% in 2012 of the nation's foreign exchange earnings (Ibanga, 2011; CBN, 2012). About 36 Billion barrels of crude oil reserve and 19.2 Billion cubic meters of natural gas is deposited in the country. This paper assesses the implementation of the deregulation policy in Nigeria (2003-2012), with a focus on the Nigerian National Petroleum Corporation (NNPC). The study used informed knowledge in providing analysis for the study. The study found out that the two major challenges inhibiting the implementation of the deregulation policy by NNPC are, price control, and effect of global market. The study recommended among others that, for Nigeria to realize its potential and reap the benefits of deregulating the sector, the NNPC must tailor the implementation of the policy in a manner that will take cognizance of the socioeconomic challenges facing Nigerians by recognizing and engaging community help services in communities where exploration takes place.

Keywords: NNPC, Deregulation Policy, Global Market, Policy, Nigeria. 


\section{Introduction}

The country Nigeria is the sixth largest oil exporter amongst OPEC members. In 2011, Nigeria was estimated to have generated $90 \%$ of its national expenditure through derivatives from crude oil (Ibanga, 2011). The crude oil reserve of the nation stands at over 66 billion barrels, production and export commenced in 1958 (Energy Commission of Nigeria, 2007). According to the Federal Office of Statistics, crude oil accounted for 13.5 per cent of the nations export earnings and by 1970, the sector was conceived as the leading source of foreign exchange earnings as a result of the oil boom in the 70s, it accounted for $63.9 \%$. By 1979, petroleum sales had completely overshadowed non-oil exports such as the agricultural sector predominantly cocoa, as a result of the boom. The Central Bank of Nigeria, Nigeria's apex bank, in 2011 argued that oil and gas exports accounted for more than $98 \%$ of export earnings, 76 percent of all government revenues and about one-third of the country's GDP (CBN, 2012).

\section{Background}

The strategic nature of the petroleum sector cannot be overemphasized in the country's economic gains in view of exploration, production, gas utilization, conservation, and petroleum policy and legislation are sensitive economic and management issues. It has been estimated that demand and consumption of petroleum grows at $12.8 \%$ annually (CBN, 2012). Nonetheless the petroleum still remains expensive and unreachable as a result of exportation of raw crude and importation of finished products (CBN, 2012). As a means to regulate the oil industry, the federal government of Nigeria established the Nigerian National Petroleum Corporation (NNPC) in April 1977 to succeed its predecessor the Nigerian National Oil Company (NNOC). The NNPC has the mandate to manage the operational aspects of the oil industry in Nigeria, while the regulatory functions reside with the Federal Government. In addition to its exploration activities, NNPC developed operational interest in refinery, petrochemicals and product transportation as well as marketing. Thus, between 1978 and 1989, NNPC constructed petroleum and petrochemical refineries in Warri, Kaduna, and Port Harcourt (NNPC, 2007).

In the last two decades, the Nigerian National Petroleum Corporation (NNPC) has emerged as largest nationally owned corporation in Nigeria. In 1978, the corporation was decentralized into twelve strategic business subsidiaries and units covering the entire 
Assessing the Implementation of the Deregulation Policy of the NNPC (2003 - 2012) 129

spectrum of the corporation's operation. This has entailed making the corporation responsible for the commercial aspects of oil and gas activity. Also, as part of efforts to put NNPC on a more commercial footing, the Federal government in March 1988 introduced a new structure for the corporation. The aim, as stated by the Federal government was to see the NNPC as a "financially autonomous" and "commercially integrated" company.

Accordingly, in 1978 three new areas of responsibility were initiated for the Corporation: Corporate Services, Operations and Petroleum Investment (NNPC 2007). In 1989, two additional Subsidiary Business Units (SBUs) were established: the Integrated Data Services Company (IDS), and Eleme Petrochemicals Company which was established and commissioned "to provide the basis for the expansion of a petrochemicals and plastics industry" (International Directory of Company History, 2005:3).

Again between 1978 and 1989, the NNPC constructed refineries in Warri, Kaduna and Port Harcourt (NNPC, 2007). The activities and operations of the refineries fall under what is referred to as Downstream Operations of the NNPC, which cover oil/gas conversion into refined and petrochemical products. As an autonomous Federal Government owned corporation, the Department of Petroleum Resources (DPR) - a Department within the Ministry of Petroleum Resources - regulates the activities of the NNPC (NNPC, 2007). Over the years, the operations and activities of the NNPC have centred on coping with challenges of dealing with developments in the oil industry, particularly with regards to its products. The concern has been how to make its products compete favourably in the world market, both in terms of pricing and quality. As a result, the business units and subsidiaries of the State Owned Oil firm have been reorganized and unbundled into companies with NNPC as a holding company.

The campaign for the deregulation of the oil sector was perceived as the most reliable measure towards resolving the scarcity of the petroleum products in the country, which the Former Minister for Information and Communication Jerry Gana at a press briefing, disclosed government's intention to deregulate the oil industry hinging the stance on distortion, which the smuggling syndicates exploit to cause scarcity (Gana, 2001). In same vein, the Former Group Managing Director of NNPC, Mr. Jackson Gaius Obaseki accused the petroleum marketers of creating artificial scarcity via diversion, hoarding and smuggling of products to neighbouring countries. Taking into cognizance the plea of the oil marketers, Gana argues that the government have considered all 
shades of opinion, before deciding that deregulation is the answer to the problem confronting (scarcity of petroleum product) the oil sector (Ibah and Oladipo, 2001).

Full deregulation is viewed as a panacea for the distribution of petroleum product across the country, which gave rise to the town-hall meetings between the government and the organized labour (NLC) on the complete removal of fuel subsidy and deregulation of the downstream sector of the oil industry. According to Ayodele, deregulation is one essential aspect of price and market reforms which entail both unshackling private sector development through removal of government restrictions on private economic activity and divestiture of the state assets particularly Public Enterprises (PEs) into private hands (Ayodele, 1994). The main objectives of deregulation include: introducing a market economy, increasing economic efficiency, establishing democracy and guaranteeing political freedom as well as increasing government revenue (Dhaji and Milanovic, 1991). Kupolokun, the former Group Managing Director of NNPC, noted that the intended goals are to:

- Dismantle the natural monopoly of the state owned enterprise by privatizing and deregulating price controls.

- Create competition in the downstream sector by encouraging more companies to get involved and eventually supplying the market at competitive pricing levels.

- Reduce the cost government spends on subsidizing the sector which runs as high as $\$ 1.5$ billion annually, which can consequently be used to handle socioeconomic and welfare needs of the Nigerian people.

- Boost Foreign Direct Investment to the Nigerian economy.

- Reduce transportation costs of products and people (Kupolokun 2004).

The government made the first move at full deregulation of the downstream sector in 2003. Partial deregulation has however been in place some years before 2003. In order to speed up the full deregulation policy, the Federal Government inaugurated a Special Task Force with responsibility to produce a harmonized version of the Bill, which would be presented to the legislature for passage. The Petroleum Industry Bill is a 223-page legislation, which seeks to revise, update and consolidate existing petroleum sector 
Assessing the Implementation of the Deregulation Policy of the NNPC (2003 - 2012) 131

related legislations in Nigeria. According to Reginald Stanley (2009) Managing Director of PPMC, the objectives of the Bill are:

- To create a conducive business environment for petroleum operations;

- To enhance exploration and exploitation of petroleum resources for the benefit of Nigerians;

- To optimize domestic gas supplies particularly for power generation and industrial development;

- To establish a progressive fiscal framework that encourages further investment in the petroleum industry while optimizing revenues accruing to the government;

- To establish commercially oriented and profit driven oil and gas entities;

- To liberalize the downstream petroleum sector;

- Creating efficient and effective regulatory agencies;

- To promote openness and transparency in the industry; and

- To encourage the development of Nigerian content (Stanley 2009).

As expected, public opinion about deregulation in Nigeria covers a wide spectrum, and cuts across all sides of the argument. The Save Nigeria Group (SNG), a civil society organization during the protest on the removal of fuel subsidy in Lagos, believes that the Nigerian petroleum industry should not be liberalized, or deregulated, or privatized completely, and that the status quo should remain, maybe with some minor fine-tuning made to improve efficiency in the overall national interest. The Nigerian Labour Congress (NLC) holds the view that deregulation of the petroleum industry in Nigeria should be implemented in phases, so as to enable the state-owned monopolies to regain efficiency, before their full privatization. However, the Government insists that complete deregulation, including the total, and final dismantling, unbundling, and subsequent wholesale privatization of all state-owned petroleum businesses, should proceed without further delay, with maximum dispatch, for the continued and meaningful survival of the Nigerian petroleum industry in the $21^{\text {st }}$ century (Braide, 2003).

The deregulation policy suffers mostly from the wide resentment from majority of Nigerians, especially as it bothers on the removal of fuel subsidy, which is seen as one of the essential requirements of the deregulation policy. The removal of fuel subsidy results in the hike in the price of petroleum products, which has devastating effect economically 
on the standard of living of ordinary citizen who rely on it for fuelling their generator set and vehicles. The concepts used in this study will further be positioned.

\section{The Concept of Deregulation}

In popular parlance, to deregulate means to do away with the regulations concerning financial markets and trades, as Ernest and Young point that deregulation and privatization are elements of economic reform programs charged with the ultimate goal of improving the overall economy through properly spelt out ways (Ernest and Young, 1988). For example, relieving government from the bondage of continuous financing of extensive projects which are best suited for private investment by the sale of public enterprises; encouraging efficiency and effectiveness in resources utilization; reducing government borrowing while raising revenue; promoting healthy market competition in a free market environment; improving returns from investment and broadening enterprises share ownership, thus engendering capital market development (Izibili and Aiya, 2007:228). Put differently, deregulation in the economic sense means freedom from government control (Innocent \& Charles, 2011). According to Akinwumi et al (2005), deregulation is the removal of government interference in the running of a system. This means that government rules and regulations governing the operations of the system are relaxed or held constant in order for the system to decide its own optimum level through the forces of supply and demand (Ajayi and Ekundayo, 2008).

Deregulation allows enterprises and services to be restricted as little as possible. It includes total withdrawal of government controls in the allocations and the production on goods and services. Deregulation of a country's economy could be conceptualized as divestiture or market economy. This refers to private participation in a country's economic activities. It is to ensure competitive economic system devoid of monopoly and allow price mechanism of demand and supply principle of the economy to prevail. According to Ahmed, deregulation entails giving greater space to the private sector as the prime mover of the economy, contrary to emphasis on the dominance of public sector. To achieve this objective, greater roles are assigned to market factors as against rigid regulation by the government (Ahmed 1993). It is aimed at stabilizing and restructuring the economy for a durable growth. Ayodele agrees and argues that deregulation is an essential aspect of price and market reforms that entails two basic assumptions, unshackling private sector development through removal of government 
Assessing the Implementation of the Deregulation Policy of the NNPC (2003 - 2012) 133

restrictions on private economic activity and, secondly, divestiture of the state assets particularly Public Enterprises (PEs) into private hands (Ayodele, 1994).

Dhaji and Milanovic have identified four essential objectives of the deregulation to include: introduction to a market economy, increase economic efficiency, established democracy, and guaranteed political freedom, as well as increasing government revenue (Dhaji and Milanovic, 1991). The concept of deregulation is premised on the neoliberal school of thought, which doctrine is based on competition and profit motive, founded on free market pricing and freedom from the interfering hands of state regulation (Wikipedia, 2011). Deregulation according to neoliberalist school of thought is to reap the advantages of the market system and competition namely: effectiveness, productivity, and efficient service, which is in tandem with the principles of private owned firms (privatization), that is, to strengthen market forces with some degree of deregulation, economic liberalization, relaxation of wage and price controls (Ugorji, 1995). The ideological framework of the concept (deregulation) is derived from international capitalist imposition ideology of especially the World Bank/IMF that encourages economic liberalism/privatization as pre-conditions for loans to the less developed countries (LDCs) (Ugorji, 1995). Ugorji further argues that privatization and deregulation has become an acceptable paradigm in the political economy of states especially LDCs seeking aids from the WB or IMF. According to Aluko, the assumption of the inherent efficiency of the private sector should be questioned. In that, in Nigeria, much of private sector profits are not always the result of efficient operation and increased productivity rather often represent money that private contractors make through inflated contracts, patronage, corruption, public sector connections and influence (Adeyemo, 2005). This has subsequently questioned the private sector ventures in the petroleum industry.

\section{NNPC and the Business Arrangement in the Petroleum Industry}

The Nigerian oil and gas sector plays a very dominant role in the nation's economy with over 98\% of the nation's foreign exchange earnings drawn from the sale of crude oil (Atakpu, 2007). Nigeria has about 36 billion barrels of crude oil reserve and 19.2 billion cubic meters of natural gas. It is estimated that the country has realized about 600 billion US dollars since 1956 when it first discovered oil in commercial quantity in Oloibiri, present day Bayelsa state, from oil and gas (Atakpu, 2007). Besides the large crude oil and natural gas deposits, there are also deposits of gold, tin, talc, gemstones, 
kaolin, bitumen, iron ore and barites that can be harnessed to earn foreign exchange for the country; yet oil and gas remain the country's major source of foreign exchange earnings and revenue base (Adebola, 2006).

Indeed, over the years, oil has become the main stay of the Nigerian economy as the earnings from crude oil are used for infrastructural developments and other improvements on the socio-economic wellbeing of Nigerians (Augusto, 2002). The Nigerian government earns income from oil through the sale of crude oil and gas; Petroleum Profit Tax (PPT), royalties and rent from industry operators.

Three major business arrangements are operated in the industry via:

(1) Joint Ventures (JV), also called Joint Operating Agreements (JOA), between the Federal government and multinational operators, such as Shell, Agip, Chevron and Elf.

(2) Production Sharing Contract (PSC), or arrangements between the government and operators, where NNPC acts as concessionaire, usually in the deep offshore operations where the operator funds exploration, development and production activities and revenues are shared between both parties.

(3) Service Contract (SC) i.e. where Oil Prospecting License (OPL) title is held by the NNPC while the operator designated as the service contractor provides all the funds required for exploration and production works. In the event of a commercial find, the contractor recoups his cost in line with the procedures stipulated in the contract. The difference with the PSC is that while the SC covers only one OPL, the PSC may span more than two or more OPLs at a time. The SC covers a fixed period of five years and if the efforts do not result in commercial discovery, the contract automatically terminates. (Augusto, 2004).

According to Ariweriokuma, the oil sector is divided into two: upstream and downstream where oil and gas activities takes place. The upstream sector involves the operations in the areas of Exploration and Production (E\&P) as well as services that lead to these E\&P activities (Ariweriokuma, 2009). The Nigerian government is a major investor in the production activities of the upstream sector coordinated by the NNPC (Nwosu, 2007). The downstream sector involves refining the products from crude oil and the distribution of the products to final users. Basically there are three main functional 
Assessing the Implementation of the Deregulation Policy of the NNPC (2003 - 2012) 135

areas within the downstream sector: refining, distribution and marketing of petroleum products. The downstream sector is of strategic importance to the nation, as petroleum products constitute a key source of energy for various purposes (Obasi, 2003), mostly due to the electricity crisis bedevilling the country.

However, despite the country been a major oil producing country for decades, and accruing huge revenues from oil, Nigeria is ranked $14^{\text {th }}$ on the fragility index in 2015 amongst 176 rated nations across the globe as a result of its inability to reach the MDG goals. Also, the lack of equitable distribution of the oil wealth and environmental degradation resulting from exploration activities have been identified as key factors aggravating actions from environmental rights groups, inter-ethnic conflicts, and civil disturbances from ethnic militias such as the Movement for the Emancipation of the Niger Delta (MEND) and Niger Delta Vigilante Force (NDVF) (NDDC Report). To Warner, Nigeria case is similar to a number of oil rich countries where their governments have failed to translate their oil wealth into economic sustainability and higher standards of living, stressing that literature abounds on these issues of 'resource curse' and 'Dutch disease' (Warner, 2007). Wunmi argued that to curb this menace in the oil sector pragmatic petroleum development policy framework, with serious emphasis on managing revenue flows and expectations are needed while creating linkages with nonpetroleum sectors. Thus, expansion of local capacity and infrastructure development, human capacity building, managerial skills, advancing technical progress and entrepreneurship with transparency and accountability could be exerted (Wunmi (2007).

The first Oil and Gas Sector Reform Implementation Committee (OGIC) inaugurated in the Obasanjo regime in 2000 to separate the commercial institutions in the oil and gas sector from the regulatory and policy-making institutions of the NNPC had little or no significant success. However his (Obasanjo's) administration did not completely put into operation the recommended OGIC policy instruments, to facilitate oil and gas sector institutional restructuring. In 2007, however, the government of President Umaru Yar'Adua reconstituted OGIC headed by Rilwan Lukman a Former NNPC Manager saddled with responsibility of the broad provisions in the NOGP into functional institutional structures that are legal and practical for the effective management of the oil and gas sector in the country. The mandate basically called for a restructuring of the petroleum industry in Nigeria that can facilitate the propelling of the national economy to a GDP level comparable to the top 20 largest worldwide economies by 2020 . This led 
to the Petroleum Industry Bill, which was passed in 2012. Furthermore, the Jonathan administration heightened the call for the deregulation of the downstream sector, which was vehemently opposed by the civil society. Government argument on deregulation of the downstream oil sector is premised on the expectation that it will improve the efficient use of scarce economic resources by subjecting decisions in the sector to the operations of the forces of demand and supply. Appropriate pricing of petroleum products is one of the major factors that will attract private investment into the Nigerian downstream petroleum sector, thereby increasing competition, promoting overall higher productivity and, consequently, lowering prices over time. Independent oil marketers would be free to set their prices. This would lead to further reduction in prices for refined oil product until an appropriate market price is attained. Continued subsidization by the government will not help achieve such appropriate pricing. Deregulation through subsidy removal will lead to adjustments that will push prices towards its marketdetermined level. Though, appropriate pricing was achieved however the policy did not make activities in the sector more profitable and attractive to private domestic and foreign investors. The ultimate effect of this chain of activities is increased gains for the citizens; of exceptional note is the privatization of the telecommunication sector in the country, which led to a significant reduction in call tariffs, and sim-pack purchase. Similar successes have also been recorded in the banking sector with the emergence of stronger banks with unprecedented spread to several other African countries example of Guarantee Trust Bank, Ecobank Transnational, etc (Richard, 2012). Furthermore, the resultant effect of deregulation by the government was to reduce economic waste and lighten social burdens caused by government control is yet to be achieved, though scarcity of the commodity was reduced substantially however the effect on the price of the commodity is still yet to be achieved.

Deregulation of the downstream oil sector, remain the path forward in expanding opportunities for economic growth and a competitive downstream sector. If regulation is limited to oversight and supervisory functions, aimed at guaranteeing quality of products and preventing consumer exploitation, then the process of deregulation could help achieve greater cost-effectiveness. Richard (2012) further asserted that research and analysis showed that even if all the country's refineries were to operate at full capacity, there would still be a petrol supply gap of 15 million litres per day. Therefore, importation will remain inevitable until additional refining capacities are built through 
Assessing the Implementation of the Deregulation Policy of the NNPC (2003 - 2012) 137

the on-going Greenfield Refinery Project. Discussions are currently under way with prospective investors who are willing to provide Foreign Direct Investment (FDI) to build additional refineries in the country to ensure domestic self-sufficiency and the export of refined petroleum products within the next few years. The Petroleum Industry Bill (PIB) contains special fiscal incentives in place to encourage the establishment of new refineries around the country. A viable local refining sector will, in the long term, bring down the pump price of petroleum products below the current import parity level.

The downstream sector of the oil and gas is currently partially deregulated, making it difficult for prices of petroleum products to be market determined. The sector was regulated, with government maintaining a monopoly of supply of petroleum products and few oil majors dominate it. The dominance of these firms in the market has made the Petroleum Marketing Industry in Nigeria an oligopolistic one. It could therefore be described as the survival of the fittest. Due to the market structure, the leading marketers dictate the trends in the market while the fringe independent marketers struggle to match up with the competition (Mars, 2009). However, in line with the nation's economic reform agenda that was launched in the 1980s but effected gradually till date, policy makers have embarked on a regime of full deregulation of the sector, which was intended to remove price control mechanisms that have undermined the growth of the sub-sector in previous years, allowing private stakeholders to complement the government efforts in developing the industry (Aigbedion and Iyayi, 2007).

\section{State of the Down Stream Sector in the Partial Deregulation Era}

(a) State of the Refineries: According to Ibiyemi (2004), the downstream oil subsector has been constrained by the unenviable state of the nation's refineries, which have being producing at minimal capacities in the past years, despite huge expenses incurred on Turnaround-maintenance (TAM). Poor maintenance of Nigeria three refineries located in Warri, Port Harcourt and Kaduna with a combined installed capacity of 445,000 bpd, led to a drastic fall in production level to $15 \%$ of the total installed capacity. The sudden closure of the Kaduna and Warri refineries during this period, so as to allow for TAM, contributed to the decrease in production of refined products. The development led to massive importation of petroleum products to fill demand gaps that exist in domestic consumption. According to Maram (2012), Nigeria, Africa's top oil producer, 
relies on imports to meet about 70 percent of its domestic fuel needs, due to lack of refining capacity. However, the huge cost associated with importation of petroleum products was a major reason for government emergent reform and the hike in prices of petroleum products over the years. In addition, government has signified its intention to relinquish its holding in the nation's refineries and make its percentage holding available to the private investors. This is expected to complement its efforts toward complete deregulation of Nigeria's oil industry.

(b) Product Availability: In 2003, the NNPC announced a program of deregulation for the sector, which was aimed at stimulating adequate supply of petroleum products, fostering appropriate pricing mechanisms and eliminating sharp practices in the industry. The policy framework discontinued government monopoly on the importation of petroleum products, thereby opening the investment field for private investors and stakeholders in the industry to source their products. However, this policy allowed independent marketers to determine prices of petroleum products in line with their cost of supplies. This development generated a deep concern, particularly in the ranks of organized labour, which saw the policy shift as capitulation of government to the demands of oil marketers against the interest of consumers.

According to Kolawole (2012), despite the nation's huge endowment of crude oil and gas and the extensive infrastructures available in the sector for distribution and marketing of petroleum products, the downstream sector has been hit by increase instability, hallmarked by a dearth of product to supply. During this period, sharp practices thrived in the industry with independent marketers arbitrarily hiking prices beyond approved rates. Product adulteration, diversion/smuggling, bunkering, and other illegal acts were very common. Indeed, official prices rose sharply from 26 to 65 (naira) per litre between 2002 and 2011 and to 95 (naira) per litre in 2012. The sector is characterized by supply uncertainty; fuelled by the mismanagement of the nation's refineries.

Furthermore, the House of Assembly probe of the Sub-sector in 2012 revealed that in 2011, the Independent Petroleum Marketers Association of Nigeria (IPMAN) got less than $1 \%$ of the fuel importation contracts, compared to the huge number of its retail outlets and storage facilities. The association 
called on the Federal Government to remove the 'briefcase contractors' from the system and ensure that regulatory agencies did not provide a platform that encouraged cutting of corners. This indicated that the fuel distribution system in the nation was defective, resulting into perennial scarcity of the products.

(c) Fraud and Smuggling: Apart from the Indigenous Ship Owners Association of Nigeria (ISOAN) accusation that NNPC had engaged in shady deals with foreign ship owners due to the preferences given to foreign ship owners in the shipment of crude oil over the indigenous owners which short-changed Nigeria as she lost as much as N3.7 trillion monthly in freight or shipping costs. A civil society activist, Barrister Femi Falana also opined that, while the petroleum ministry estimated national fuel consumption of 35 million litres a day, the government paid subsidies on 59 million litres daily in year 2011. NNPC promoted smuggling by importing 59 million litres of PMS when the local consumption is not more than 35 million litres per day. He noted that some of the Marketers were overpaid for jobs done.

(d) Revenue Maximization: According to Kolawole (2012), The Nigerian Ports Authority (NPA) claimed at the legislative probe of the sector in 2012, that it had granted waivers to the Nigeria National Petroleum Company (NNPC) to the tune of N1.77 billion and $\$ 135.39$ million between July 2009 till date on the orders of the Federal Government, while the corporation was owing NPA about N6 billion. The Nigerian Custom Service also stated it was sidelined in the subsidy regime, thus, the importers were not charged for imports. These indicated a gross lost of the needed revenue for developmental purposes.

According, to Tosanwumi (2012), despite robust opposition to government's full deregulation of the Nigeria downstream sector, the reform agenda has continued unabated. As a result, the nation's refineries are being offered to investor, while a number of private refineries are being approved to commence business in Nigeria. Moreover, industry analysts have arrived at a consensus that allowing private investors to own and operate refineries in Nigeria's oil industry would revolutionize the sector and erase government monopoly on the refineries. There is also a widespread agreement that deregulation of the industry, in the long run will foster price stability and generate a regular supply of petroleum products. This trend should usher in a new dawn in the 
downstream sector and generate growth, prosperity and sustainable development in the nation's most strategic industry. However, there is need for the NNPC to become more transparent and accountable to win the trust of the citizens on its quest for full deregulation of the downstream sector. This explanation should come with enough integrity to win over the 160 million Nigerians. The citizens should not be seen as bearing the brunt of government's inability to curb profiteering by a few bunkering cabals. The deregulation policy must come with palliative packages, measures and interventions to reduce the incidence of poverty, resulting from hyper-inflation and widespread sufferings among the vulnerable group in society.

The issues of power supply and other critical infrastructural facilities need to be addressed before any meaningful deregulation can be effected to engender foreign direct investment. The government needs to push for greater accountability and good governance to ensure a more transparent deregulation process that will respond to market enterprise and tickle down effect. This will evidently re-assure would-be foreign and domestic investors. Hasty deregulation therefore, in a weak environment as that of Nigeria should be avoided, for more sustainable results.

\section{Theoretical Framework}

The theoretical framework for this work is the general equilibrium theory. A French economist, Leon Walras propounded the theory in the 1870s. Arrow, Debreu and Mckenzie have developed the concept of the model in the 1950s. The main tenets of this theory indicates the relevance of efficient pricing in ensuring optimal allocation of society's limited resources for efficient production of the various needs of society and efficient distribution of the commodities and services among various consumers. Thus, the concept of perfect competition and free market imply that the general equilibrium theory will tend to yield an optimal allocation of resources since competitive equilibrium prices ensures that supply and demand are equal and in the long-run, all firms which can produce profitably will enter the industry to ensure long-run stable and sustainable growth (CBN, 1993). It is obvious that such optimality results cannot be achieved under centralized planning or command economies, which depend on elaborate control. This is because such system is hardly able to arrive at a set of efficient prices, which will ensure that all firms maximize their profits by covering their costs and earning reasonable margins, while consumers maximize their unity. 
In recent times, there has been some ferment in economics about the role of the state in economic life (Killick, 1989). Traditionally, the state's economic role has been defined in terms of a reasonability to correct or eliminate various market failures, which place serious limitations on the efficiency of the free market and justify the need for government intervention. Foremost among these are failures of competition, existence of externalities, incomplete markets, information failures, public/merit goods, macroeconomic instability, creative failures, and poverty/inequality. Although development economists no longer assume that the existence of market failures constitutes adequate cause for state interventions. This is because experience, especially in the peculiar circumstances of developing country, has taught that government has a duty to rectify these failures through the use of taxation and subsidies to moderate if not remove the observed distortions arising from the market failures. Even among the Socialist Economist (Social Democrat), the case of market deregulation is widely accepted.

At this juncture, applying the theory of general equilibrium to the deregulation policy, it is axiomatic to posit that the implementation of the deregulation policy in the downstream sector of the petroleum industry is driven by the federal government intervention to the dismantling and unbundling of the natural monopoly of the state owned enterprise (NNPC) by privatizing and deregulating price controls in order to create competition in the downstream sector, by encouraging more private companies to get fully involved and eventually supplying the market at a competitive pricing levels, as the market will self-regulate itself and prices of refined petroleum products will be sold at the natural market level as competition forces prices down.

\section{Consequence of Deregulation}

Deregulation pre-supposes market forces as the determinant of prices rather than a decision to fix price by administrative fiat. From the findings of this study, there is a vivid confirmation that NNPC's major challenges in the implementation of the deregulation policy has been the inability to attain a stable price for petroleum products which had led to product unavailability and increase in the price of petroleum products as official prices of petroleum products rose sharply from 26 to 65 (naira) per litre between 2002 and 2011 and to 95(naira) per litre in 2012. 
Deregulation is seen as the process of freeing federal government of its concurrent control and involvement in the businesses of refining, importation and distribution of refined petroleum products in the Nigeria market. The implementation of the deregulation policy in the downstream sector of the petroleum industry is evident by the federal government intervention to the dismantling and unbundling of the natural monopoly of the state owned enterprise (NNPC) by privatizing and deregulating price controls in order to create competition in the downstream sector. Government argument on deregulation of the downstream oil sector is premised on the expectation that it will improve the efficient use of scarce economic resources by subjecting decisions in the sector to the operations of the forces of demand and supply. Appropriate pricing of petroleum products is one of the major factors that will attract private investment into the Nigerian downstream petroleum sector, thereby increasing competition, promoting overall higher productivity and, consequently, lowering prices over time. Independent oil marketers would be free to set their prices. This would lead to further reduction in prices for refined oil product until an appropriate market price is attained. Continued subsidization by the government will not help achieve such appropriate pricing. Deregulation through subsidy removal will lead to adjustments that will push prices towards its market-determined level. Appropriate pricing achieved through this policy will make activities in the sector more profitable and attractive to private domestic and foreign investors.

The intention of the Federal Government since 1991 was that, the planned deregulation of the downstream petroleum industry in Nigeria was to be implemented in phases, so as to enable the state-owned monopolies to regain efficiency before its full privatization. However, petroleum products are unavailable to most Nigerians and are quite costly, because almost all of the oil extracted by the multinational oil companies is refined overseas, with only a limited quantity supplied to Nigerians themselves. The cost of importing petroleum products has increased so rapidly in recent years that it is threatening the country's balance of payment and capital expenditures (CBN, 2012).

The federal government through the Nigerian National Petroleum Corporation (NNPC) had been spending lots of money daily subsidizing imports of petroleum products. The NNPC buys at the prevailing international price, since its refineries are producing less than $30 \%$ of their installed capacity. Hence, Nigeria exports and uses the proceeds to import refined fuel for local consumption. It is against this backdrop, the 
Assessing the Implementation of the Deregulation Policy of the NNPC (2003 - 2012) 143

complete removal of fuel subsidy and deregulation of the downstream sector of the oil industry is advocated by the government.

The downstream sector of the oil and gas is currently partially deregulated, making it difficult for prices of petroleum products to be market determined. The sector was regulated, with government maintaining a monopoly of supply of petroleum products. The dominance of these firms in the market has made the Petroleum Marketing Industry in Nigeria an oligopolistic one. Due to the market structure, the leading marketers dictate the trends in the market while the fringe independent marketers struggle to match up with the competition. The dominance of these few oil majors in the downstream sector is as a result of the fact that NNPC lacks the capacity to import enough petroleum products for the country, couple with the perennial malfunctioning of the refineries, the government introduced the Petroleum Support Fund (PSF), from which it draws money to pay the excess expenditure incurred by the marketers for importing and selling petrol at regulated price and distributing it to every part of the country. The Farouk Lawan led House of Representatives' Ad-Hoc committee on fuel subsidy probe of the sector in 2012, however indicted the NNPC and major oil marketers, who took advantage of the massive corrupt loopholes in the system.

The major oil marketers engaged in falsifying the dates of bills of lading to reflect particularly high market prices. By so doing, they overcharged the Nigerian National Petroleum Corporation (NNPC). According to the report, over $\$ 300$ million has been overpaid by NNPC for fuel import. Farouk Lawan raised further posers: "How could the nation be made to pay for 59 million litres daily when we consume only 35 million daily? The balance of 24 million litres per day might be the area of sharp practices. By making that provision, you are encouraging smuggling because we know that this 24 millon litres balance would simply be smuggled out of the country since it has been paid for already and we cannot consume it." It would be recalled that in KPMG's "Interim Review of NNPC" dated 22 November 2010, the auditor said it had found that NNPC's subsidy claims and PPPRA's verification were based on the volume of petroleum products available for sale (volume of products imported and actual production from refineries) as against duly verified volume of products lifted out of the depots (volume of petroleum products sold) as stipulated in the subsidy guideline. This laid credence to the fact that major oil marketer made excess profit at the expense of the country and her citizens, making the payment on fuel subsidy unbearable for the government to sustain. 
Also, the Petroleum Marketing Industry in Nigeria is dominated by cartels who manipulate prices, through artificial supply restriction. These cartels determine volume of importation and the proportion that should be released to the market. At times, they only allow a few product holders to supply the market, while others hoard. Peter Akpatasan President of NUPENG has stated thus: "Deregulation cannot work in a market dominated by a cartels. This cartel is so strong that it can continue to manipulate prices out of the reach of common man. You cannot deregulate when you have no refineries. There will be serious economic crisis" (Democratic Socialist Movement, 2009). The sector is characterized by supply uncertainty; fuelled by gross inefficiency and mismanagement of the nation's refineries.

\section{Recommendation}

Taking into consideration the whole gamut of the research study, the following recommendations suffices:

(1) For Nigeria to realize its potential and reap the benefits of the deregulation policy there is the need to tailor the formulation and implementation of reforms in manner that will take cognizance of the socio economic challenges facing Nigerians. This would prevent the wide resentment from majority of Nigerians especially as it involves the removal of fuel subsidy, one of the requirements of the deregulation policy.

(2) Government should create an enabling environment to engender private investors' for the purpose of improving the local refining capacity to meet the ever-increasing local demand of petroleum products and indeed for exportation purpose. The continued importation of refined petroleum products whilst exporting crude petroleum is detrimental to the Nigerian economy and importation must be viewed as a very short-term measure aimed at ameliorating the cost of living for Nigerians immediately. However, the past efforts to sell the refineries have not been very successful because of the age and poor state of the refineries. I, therefore, believe that the federal government must keep an open mind about the feasibility of selling these refineries and ensure that the options of Green field or environmental-friendly refineries are actively promoted alongside efforts to sell the existing refineries. The availability 
of open general licenses will also improve competition and should result in a reduction in the cost of petroleum products, provided there is sincerity and transparency in the issue of these licenses.

(3) Nigeria's resources need transparent and accountable management. Related to the above is the need to use the oil windfall proceeds and the savings realized by the federal government from the withdrawal of subsidy channelled towards fixing the refineries, build new ones or upgrading and developing of infrastructure within the polity, in areas such as waterways, rail and mass transit system, thus providing cheaper alternative transportation methods.

(4) Corrupt practice and elements in the downstream sector should be quickly identified and punished without fear or favour, so that the huge leakages currently associated with the subsidy scheme could be curbed. Government's commitment to accountability, corporate governance and responsibility as core values by all the stakeholders in the sector will go a long way in rebuilding the trust of Nigerians in deregulation of the oil sector and other subsequent reforms. To attain this, there is a need for a strong pro-competition and antitrust law to be put in place to regulate the industry, instead of nurturing an oligopoly of government cronies.

(5) Finally, the full deregulation of the downstream sector should proceed with the passage of the Petroleum Industry Bill (PIB) that will help revise, update and consolidate existing petroleum sector related legislations in Nigeria.

\section{Conclusion}

While the reform process has made quite some gains, yet there remain many challenges. The most notable of these challenges is the inability of the Nigerian National Petroleum Corporation (NNPC) to attain a stable price for petroleum products, which had led to products unavailability and increase in price of petroleum products. The downstream sector is characterized by supply uncertainty; fuelled by gross inefficiency, mismanagement of the nation's refineries despite massive injection of funds and, most importantly, poor thorough monitoring of major oil marketers and the lack of political will to tame the monster of official and unofficial corruption among other problems. 
The current state of the downstream sector is judged as inefficient in service delivery and ineffective at promoting national developmental objectives, in that the rationale for the proposed restructuring in the oil and gas sector in a petroleum dependent economy like Nigeria was to enhance the sustainability of petroleum wealth and its impact on all sectors of the economy. This notwithstanding, such reforms or restructuring must not only focus on enhancing industry effectiveness and efficiency, it must be mindful of equity issues with respect to wealth distribution among all the sectors of the national economy.

In Nigeria, the focus of the reform should be for the oil and gas institutional structures and regulatory framework to maximize the economic benefits of petroleum resources, for the current and future generations. The policy should facilitate economic prosperity for an average citizen in Nigeria. However, the caveat issue to keep in mind is that the petroleum downstream sector deregulation should produce efficiently, effectively and equitably, which could result in durable infrastructures and human capital for sustainable development of the national economy.

\section{List of References}

- Abubakar, A. 2001. How to end fuel shortage by ex-PPMC Boss, edited by Nwora, C; "Guardian" Newspaper, 3/06/01, pp1-2

- Adigun, B.A. 1993. Averting oil shortage in Nigeria - The efficiency and adequacy of supply and distribution facilities in Nigeria, Energy policy agenda, pp197

- Ahmed, A. 1993. Central Bank of Nigeria: Perspectives of Economic Policy Reforms in Nigeria, Ikeja: Page Publishers Services Ltd.

- Aigbedion, I. \& Iyayi, S. 2007. Diversifying Nigeria's Petroleum Industry, International Journal of Physical Science, 2, (10), 263-270

- $\quad$ Ali, M. S. 2001. Fuel deregulation: a symphony of discord Guardian Features, 20/02/01 
- Aluko, M.E. 2003. On the fuel price hike and why we are where we are, view point in Lagosforum.com, 2/3/03, pp1-16

- $\quad$ Ariweriokuma, S. 2009. The Political Economy of Oil and Gas in Africa: The Case of Nigeria. New York: Routledge

- Avuru, A. 2004. Ensuring Transparency in Nigerian oil industry, Thisday Perspective, 17/03/04, Рp26

- Ayodele, A. S. 1994. Elements of the Structural Adjustment Program: Privatization and Commercialization in The Nigerian Journal Economics and Social Studies, Vol. 36, No. 1.

- Braide, K.M. 1997. Guaranteeing Petroleum products self-sufficiency in Nigeria, Annual Dinner Guest Lecture of the Nigerian Society of Chemical Engineers, held at shell club Port Harcourt held between 17th and 18th November.

- Central Bank of Nigeria 1993. Perspectives of Economic Policy Reforms in Nigeria. A study Report, Ikeja: Page Publishers Ltd.

- Dhanji, F. \& Milanovic 1991. Privatization in Eastern and Central Europe:

- Ernest, P. and Young, C. 1988. "The Colonial State and Postcolonial Crisis" in Ernest P. and Young, C. The Transfers of power, 1960 - 1980. New Haven and London Tale University press

- Etekpe, A. 2007. The Politics and Conflicts over Oil and Gas in the Niger Delta Region: the Bayelsa State Experience 1990-2006, Port Harcourt: Tower Gate Resources

- Eyinla P, Ukpo J. 2006. Nigeria; The Travesty of Oil and Gas Wealth. Lagos: The Catholic Secretariat of Nigeria.

- Ezeagba, C.E. 2005. "Deregulation of Nigerian Economy: Implications for the Downstream Petroleum Industry," Certified national Accountant, July -September.

- Gaius Obaseki, J.E. 1996. "Potentials for a West African Sub-Regional Gas Market", Napetcor, Fourth Quarter

- Ikein, A. 1990. The Impact of Oil on A Developing Country: The Case of Nigeria, New York: Praeger.

- Izibili, M. and Aiya, F. 2007. "Deregulation and Corruption in Nigeria: An Ethical Response", Kamal - Raj. Journal of Sciences. 14(3): 229 - 234.

- $\quad$ Khan, S.A., 1994). Nigeria: The Political Economy of Oil, Oxford: Oxford University Press. 
- Kupolokun, F. 2006. "Challenges and Future Prospects of Oil and Gas Industry", The Guardian, Lagos, Wednesday, May 31, 2006.

- Kupolukun, F. 2005. NNPC's silent revolution, Tell Magazine Special Edition, no.8, 21/02/05 Pp1-10

- Kupolukun, F. 2007. The Nigerian Oil and Gas Industry: Consolidating the gains. A paper presented at the Nigerian Oil and gas Conference, Abuja, Nigeria.

- Misham, E. J. 1982. Introduction to Political Economy, London: Hutchinson

- Obi, C. 2007. "The Struggle for Resource Control in a Petro-state: A Perspective from Nigeria", in P. Bowles, et al; National Perspectives on Globalisation, Hampshire and New York: Palgrave Macmillan.

- Objectives, Constraints and Models of Divestiture, A World Bank Research Working Paper, No. 770

- Philips, A.O and Osayinwese, I. 1977. On the 1978 Increases in the Retail Prices of Petroleum Products, The Nigerian Journal of Economics and Social Studies, NES, vol 19(3), Nov. 1997, Pp. $307-324$

- Salami, O. and Ayoola, A. K. 2010. The 'War' of Appropriate Pricing of Petroleum Products: The Discourse of Nigeria's Reform Agenda. Linguistik online 42, 2: 4152

- Soeze, C. 2005. Deregulation of the downstream sector of the Nigerian economy, Vanguard Newspaper, 15/02/05

- Soremekun, K. 1995. "Oil and Democratic imperative in Nigeria". in Olowu et al (eds), Governance and Democratization in Nigeria. Ibadan: Spectrum Books.

- Usman, S. 2007. Nigeria: Searching the National Resource Curse, Being a paper presented at the London School of Economics and Political Science, London Oct. 11, 2007.

\section{AUTHORS' CONTACT:}

OKARAH, Anthony Chidiebere

Dept of Public Administration and Local Government University of Nigeria, Nsukka Email: okarahanthony@yahoo.com

\section{NDAGUBA, Emeka Austin}

School of Government \& Public Admin

University of Fort Hare

Bisho Campus

Email: endaguba@ufh.ac.za 